\title{
Pravěké a středověké osídlení v areálech tří současných jihomoravských nádrží
}

\section{JOSEF UNGER}

Klíčová slova: archeologie - dějiny osídlení - Pavlovské vrchy - Nové Mlýny - Vranov - Brno

\section{SOUHRN}

Všechna tři zatopená území ležela $v$ odlišném přírodním prostředí, které výrazně formovalo jejich osudy. Pro poznání proměn osídlení mají nezastupitelný význam archeologické prameny. Jestliže pred budováním Vranovské a Brněnské přehrady nebyl v předstihu proveden žádný archeologický výzkum, takže jsme odkázáni jen na poznatky z okolí, pak před budováním vodního díla na řece Dyji byl zatopený areál soustavně archeologicky zkoumán.

Rozdíly v průběhu osídlení se projevily především mezi územím v okolí vodního díla Nové Mlýny, ležícího v nížinném prostředí na dolním toku řeky Svratky a Jihlavy, které se zde vlévají do Dyje, a Vranovské a Brněnské přehrady, které leží na okraji území osídleného, zřejmě s přestávkami, po celý pravěk. Do okolí Brněnské přehrady pronikli lidé z Dyjsko-svrateckého úvalu v období neolitu a potom již zůstalo toto území až do 11. stol. neosídlené. Okolí Vranovské préhrady, ležící v Bítovské pahorkatině, bylo rovněž na okraji území vhodného pro osídlení v pravěku a časném středověku, ale přesto sem lidé pronikali s menší intenzitou $v$ různých obdobích, ale teprve kolonizace, jejíz počátky můžeme sledovat již od 9. stol. a s větší intenzitou od 13. stol., založila osídlení tohoto území trvající dodnes.

\section{ÚVOD}

Podstatným prvkem formování krajiny v odlišných prírodních prostředích byl její reliéf, nadmořská výška a sít vodotečí. Osídlení bylo dále limitováno zpưsobem obživy, hustotou obyvatelstva a dálkovými komunikacemi. Proměny osídlení Ize studovat na základě archeologických pramenů, které byly v zájmové oblasti studovaných nádrží k dispozici jen v nejnovějších z nich, kterou je vodní dílo Nové Mlýny.

\section{VODNÍ DÍLO NOVÉ MLÝNY}

Oblast Pavlovských vrchů byla velmi výhodnou pro lovce $v$ mladším paleolitu, kterým vyvýšená poloha, predevším na severních svazích, poskytovala dobrý přehled o zvěři pohybující se v koridoru mezi řekou Dyjí a zvedajícími se svahy (obr. 1). Od dvacátých let minulého století zde archeologové odkryli celou raadu sídlišt i vzácných hrobů takzvaných lovců mamutů, jejichž vyspělá kultura s řadou dokladů uměleckých děl vydobyla tomuto místu světovou proslulost, takže fáze mladopaleolitického gravettienu se nazývá podle Pavlovských vrchů či prímo Pavlova - pavlovien (jde o období před 29000 až 24000 lety) [1]. Je samozřejmé, že lovci se zrejmě dostávali i do dnes zatopeného prostoru, ale zřejmě zde nesídlili. Zato z období střední doby kamenné - mezolitu, kdy se změnil způsob lovu, který se zaměřil na menší zviřata a rybolov, jsou známa sídliště těchto lovců z několika míst na původním břehu Dyje.

Podstatná změna v obrazu osídlení nastala díky příznivým klimatickým podmínkám v polovině 6. tisíciletí př. n. I., kdy úrodné břehy řeky Dyje a př́toků osídlili první zemědělci. Ke svému způsobu života, zaměřeného na pěstování kulturních rostlin a chovu dobytka, potřebovali již jiné nástroje než lovci, a tak z vhodných hornin brousili sekerky a kopytovité klíny a provrtávali sekeromlaty. Pro uchovávání potravin a vaření již potřebovali nádoby zhotovované z vhodných hlín a vlákna spřádali do textilních látek. K trvalejšímu pobytu se již hodily stabilnější dřevohlinité domy sdružené do sídlišť Archeologové vypracovali tři neolitické kultury (kultura s lineární keramikou, kultura s vypíchanou keramikou a kultura s moravskou malovanou keramikou), jejichž stopy se nacházejí ve sledovaném území [2].

$\checkmark$ dalším archeology definovaném období - eneolitu, čili pozdní době kamenné (3500-2000 př. n. I.), pokračovalo osídlení dnes zatopeného území $\checkmark$ neztenčené míre, ale až koncem tohoto období, charakterizovaném nositeli kultury se šňưrovou keramikou a kultury zvoncovitých pohárů, je známo více nalezišt', které patrně svědčí o větší intenzitě osídlení [3]. Lidé se i nadále živili zemědělstvím a chovem dobytka, ale vedle kamenné industrie začali používat nástroje a ozdoby zhotovené z kovu, predevším mědi a do jisté míry i zlata. Přestože lidé v té době pohřbívali zemřelé, převážně uložené ve skrčené poloze na boku, objevily se i žárové hroby. Vedle toho jsou známy i situace dokládající existenci sídlištt.

Doba bronzová, která na našem území trvala přibližně od roku 2000 př. n. I. do 750 př. n. l., se vyznačuje tím, že do života lidí zasáhla slitina mědi a cínu bronz, z něhož se zhotovovaly jak nástroje a zbraně (sekery, nože, šídla, meče), tak i ozdoby (jehlice, náramky). Jinak se způsob života zemědělského obyvatelstva přiliš nezměnil. Jen jeho menší část se zabývala kovolitectvím, hrnčířstvím, tkalcovstvím a obchodem. V dobách společenského pnutí se projevila potřeba chránit se před neprítelem a to vedlo v mladší době bronzové k budování opevněných sídel - hradisek na temeni Pavlovských vrchů, kam se lidé z okolí mohli při nebezpečí uchýlit. Vzhledem k tomu, že pohřebiště bývala umístěna ve vyšších polohách než sídliště, v zatopeném území se nenacházejí [4].

Další období, nazývané archeology starší dobou železnou neboli halštatem (750 až 400 př. n. I.), znamenalo pro území pod Pavlovskými vrchy poměrně husté osídlení soustřed'ující se podél řek. Přestože tato kultura patři již do doby železné, tak železných předmětů se našlo jen velmi málo [5].

Poslední čtyři staletí před změnou letopočtu osídlilo území pod Pavlovskými vrchy lidstvo, které bylo nositelem laténské kultury a které můžeme označit za Kelty. Pro svoje sídliště si vybírali mírně vyvýšené polohy nad tokem řek, především Dyje. Díky zaměření archeologického výzkumu se ví, že sídliště tvořilo jen 


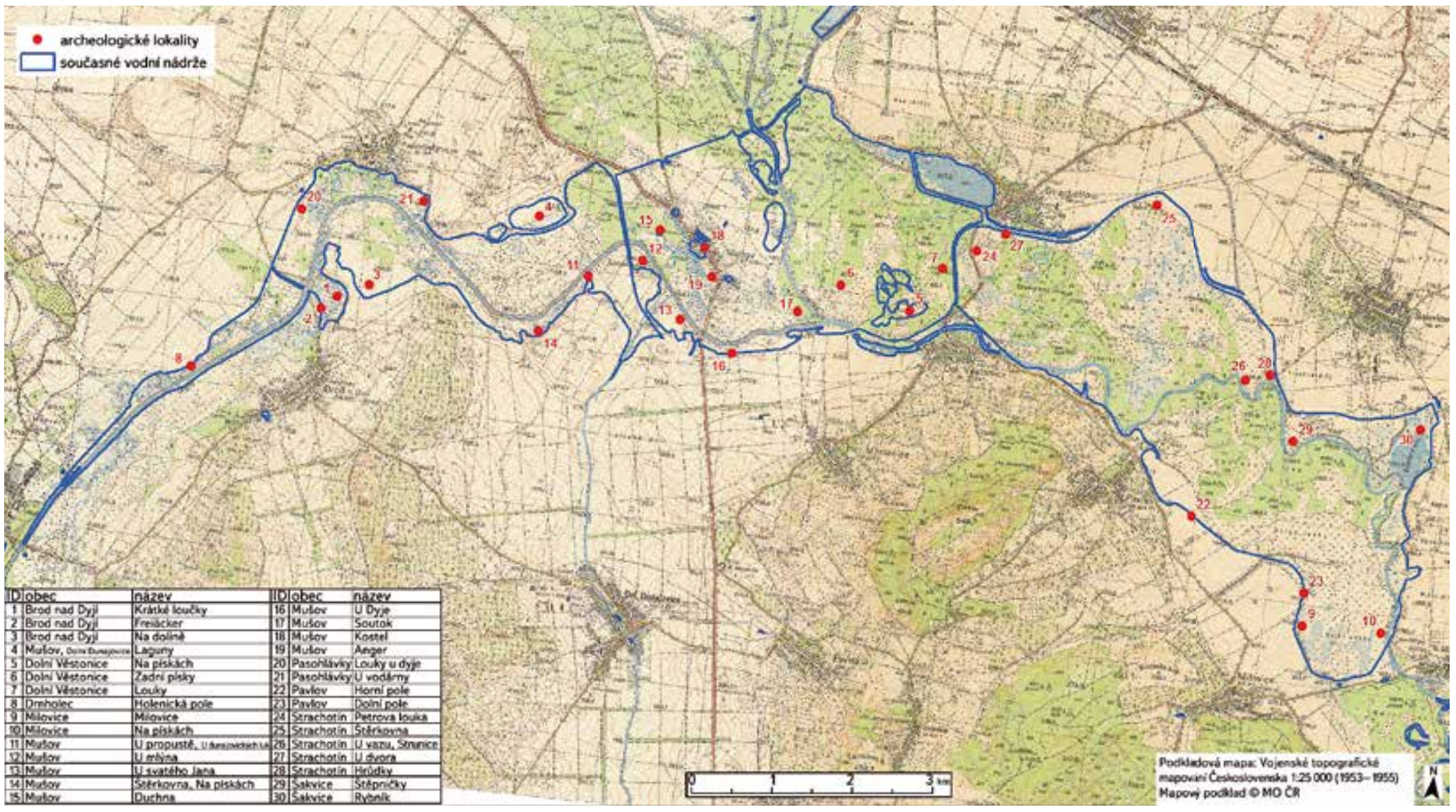

Obr. 1. Archeologické lokality pod hladinou vodního díla Nové Mlýny

Podrobný komentář je uveden v práci UNGER, J.: Zatopené kulturní a prírodní dědictvíjižní Moravy. Brno, 2016, s. 12-15, 43-44, 101, 149-158. Zde jen doklady osídlení a pobytu člověka

$\checkmark$ jednotlivých archeologicky definovaných obdobích:

P - mladší paleolit (40000-11500 př. n. I.) a mezolit (8000-6000 př. n. I.), N - neolit (5700-3500 př. n. I.), E - eneolit (3500-2000 př́. n. I.), B - doba bronzová (2000-750 př. n. I.), H - doba halštatská (750-400 př. n. I.), L - doba laténská (400-50 př. n. I.), R - doba římská (1.-4. stol.), S - doba stěhování národů (5. a 6. stol.), D - doba hradištní (6.-12. stol.), T - středověk (13. -15. stol.) a novověk

Fig. 1. Archaeological sites under the system of water reservoirs of Nové Mlýny

P - the younger Paleolithic (40000-11500 BC) and the Mesolithic (8000-6000 BC), N - Neolith (5700-3500 BC), E - Eneolite (3500-2000 BC), B - Bronze Age (2000-750 BC), H -

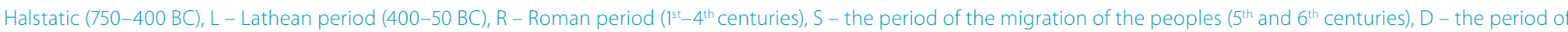
the fortification $\left(6^{\text {th }}-12^{\text {th }}\right.$ centuries), $T$ - the Middle Ages $\left(13^{\text {th }}-15^{\text {th }}\right.$ centuries) and the Modern Age

1. Brod nad Dyjí - Krátké loučky (N, L, D), 2. Brod nad Dyjí - Freiäcker (E, L, R, D), 3. Brod nad Dyjí - Na dolině (B, R, D, T), 4. Mušov, Dolní Dunajovice - Laguny (P, E, B, L, R, D), 5. Dolní Věstonice - Na pískách $(P, N, B, H, L, D)$, 6. Dolní Věstonice - Zadní písky $(P, E, H)$, 7. Dolní Věstonice - Louky $(D)$, 8. Drnholec - Holenická pole $(N, E, B, H, L, R, S, D, T)$, 9. Milovice U hráze ( $B, L, R, D), 10$. Milovice - Na pískách ( $N, E, B, L)$, 11. Mušov - U propustě, $U$ dunajovických luk (N, E, $B, H, L, R, S, D, T), 12$. Mušov - U mlýna (B, L, R, S), 13. Mušov - U svatého Jana ( $N, E, B, H, L, R, S, D), 14$. Mušov - Štěrkovna, Na pískách ( $N, E, B, L, R, S, D)$, 15. Mušov - Duchna (E, B, L, T), 17. Mušov - Soutok (L), 18. Mušov - Kostel (D, T), 19. Mušov - Anger (T), 20. Pasohlávky - Louky u Dyje (N, B, H, L, R, S, D, T), 21. Pasohlávky - U vodárny (D), 22. Pavlov - Horní pole (N, E, B, H, L, R, S, D), 23. Pavlov - Dolní pole (N, E, B, H, L, R, S, D), 24. Strachotín - Petrova louka (E, D, T), 25. Strachotín - Štěrkovna (N, E, B, H, L, S, D), 26. Strachotín - U vazu, Sturnice (N, L, D, T), 27. Strachotín - U dvora (T), 28. Strachotín - Hrůdky (T), 29. Šakvice - Štěpničky (N, E, B, H, L, R, D, T), 30. Šakvice - Rybník (N, B, H, R, D)

malé množství budov postavených ze dřeva a hlíny. Chaty na obdélníkovém půdorysu měly zpravidla zahloubenou podlahu a kůlovou konstrukci pro sedlovou střechu a sídliště bylo doplněno zásobnicovými jamami a dalšími stavbami, po nichž zůstaly jen stopy po kůlech. Kolem poloviny prvního stolet před n. I. Keltové pod tlakem změněných hospodářských podmínek odešli [6].

Okolo přelomu letopočtu osídlili sledované území Germáni patřící do svazku Svébů, a protože se jednalo o důležité místo kontrolující přechod přes Dyji, jsou zde již v 1. stol. patrny sídelní aktivity nejen Germánů, ale i Římanů. Zvláště $v$ době markomanských válek $v$ druhé polovině 2. stol. se aktivita římského vojska projevuje jednak krátkodobými vojenskými tábory a pevností v trat
„Hradisko" nad bývalým Mušovem [7]. Na zatopeném území se podařilo objevit celou řadu sídlišt germánského obyvatelstva žijícího v mírně zahloubených chatách v podstatě čtvercového pưdorysu s kůlovou konstrukcí. Germánské obyvatelstvo běžně pohřbívalo žehem, ale žárové pohřebiště $v$ zatopené oblasti nebylo nalezeno. Hrobka germánských vládců, pohřbených v nespálené podobě, byla vybavena inventářem svědčícím o přebírání životního stylu Římanů místní elitou.

Podstatná změna v osídlení území pod Pavlovskými vrchy nastala na preelomu 4. a 5. stol., kdy asi větší část germánského svébského obyvatelstva odešla a nová sít menších sídlišt se zde utvořila až kolem poloviny 5. stol. [8]. Po etnické 


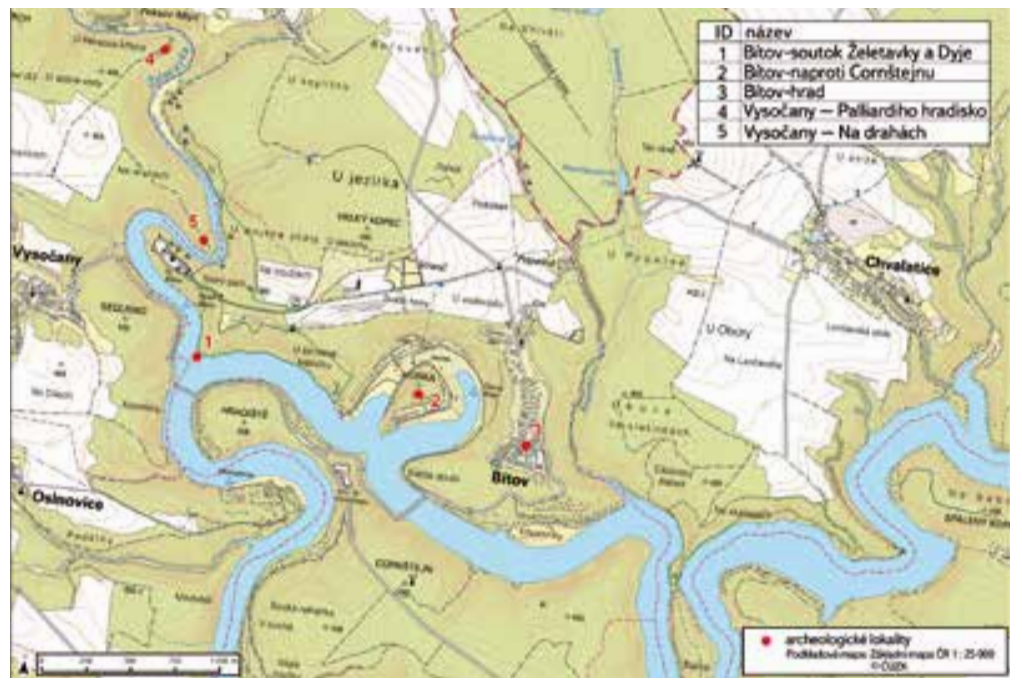

Obr. 2. Archeologické lokality v okolí Vranovské přehrady

Legenda jako u obr. 1 .

Fig. 2. Archaeological sites around the Vranov Dam

Legend is same as in Fig. 1

1. Bítov - Soutok Želetavky a Dyje (N), 2. Bítov - Naproti Cornštejnu (E), 3. Bítov - Hrad (D, T), 4. Vysočany - Palliardiho hradisko (E, B, D), 5. Vysočany - Na drahách (D)

stránce se jednalo o Germány, kteří již pohřbívali nespálená těla. Koncem 5. stol. osídlili jižní Moravu Langobardi, jejichž svéráznou kulturu známe především z pohřebišt. Kolem poloviny 6. stol. Langobardi odešli, a tak byl vytvořen prostor pro osídlení Slovany.

Slované přišli do našich zemí v 6. stol. a představili se poměrně jednoduchou kulturou pražského typu, jejímiž nositeli bylo zemědělské obyvatelstvo. Z obou břehů dolního toku Dyje je známa velká koncentrace pozůstatků jejich sídlišt sestávajících z chat se zahloubeným dnem, takzvaných zemnic [9]. Tito Slované pohřbívali zemřelé žehem, ale tato pohřebiště nebyla na sledovaném území objevena. Také z následující doby od 9. do 12. stol. je známa celá řada sídlišť venkovského obyvatelstva. Kromě toho zde leželo i hradisko Petrova louka u Strachotína, opevněné dřevohlinitou hradbou s čelní kamennou zdí, sloužící v dobách nebezpečí jako možný úkryt obyvatelstva. V areálu hradiska býval i velmožský dvorec. Souvislost s přechodem přes Dyji v těchto místech je nabíledni. Od přelomu 8. a 9. stol. Slované již pohřbívali nespálená těla a jejich hroby bývaly vybaveny keramikou, šperky i zbraněmi, jak o tom svědčí rozsáhlé pohřebiště u Dolních Věstonic. Po zániku Velkomoravské řiše zde život neustal a přechod přes Dyji kontrolovalo hradisko Vysoká zahrada u Strachotína, známé z písemných pramenů jako Strachotíngrad, ležící však již mimo zaplavené území. Hospodářské zázemí tohoto hradiska tvořila četná zemědělská sídliště v okolí.

Podstatná proměna území pod Pavlovskými vrchy se stala ve 13. stol. za kolonizace, na níž se výrazně podílelo německé obyvatelstvo [10]. V tomto období obraz krajiny pod Pavlovskými vrchy doplňovaly lesy, řeky s mlýny a některé další vesnice, které ještě ve středověku zanikly. Řeka Dyje mezi Dolními Věstonicemi a Strachotínem byla přemostěna několika mosty a $v$ Dolních Věstonicích se vybíralo mýto zemské, solné a koňské. Také u Mušova byl prechod pres Dyji a vybíralo se tam mýto.

\section{VRANOVSKÁ PŘEHRADA}

Jiná situace byla v prostředí dnešní Vranovské přehrady, která se nachází na okraji starého sídelního území (obr. 2). Život zde byl mnohem obtížnější než pod Pavlovskými vrchy. Z okolí Vysočan jsou známy nepř́liš průkazné nálezy z paleolitu. Od neolitu před sedmi tisíciletími zde žili lidé, kteří obdělávali svoje pole, pásli dobytek a pochovávali zemřelé. Další nálezy pocházejí z eneolitu, doby bronzové i starší doby železné (horákovská kultura). Osídlení Palliardiho hradiska je doloženo jak v eneolitu, tak i době bronzové i hradištní. Hospodářským, obranným i duchovním centrem byl od 11. stol. hrad Bítov, který prodělal proměnu od hradiska k středověkému hradu [11]. Městečko Bítov, jehož zbytky leží pod hladinou vodní nádrže, mělo rovněž středověký pưvod, ale v písemných pramenech se připomíná až roku 1498. Od 14. stol. střežil okolí šlechtický hrad Cornštejn, který v letech 1464 až 1465 byl po deset měsíců obléhán vojsky krále Jiřího z Poděbrad [12].

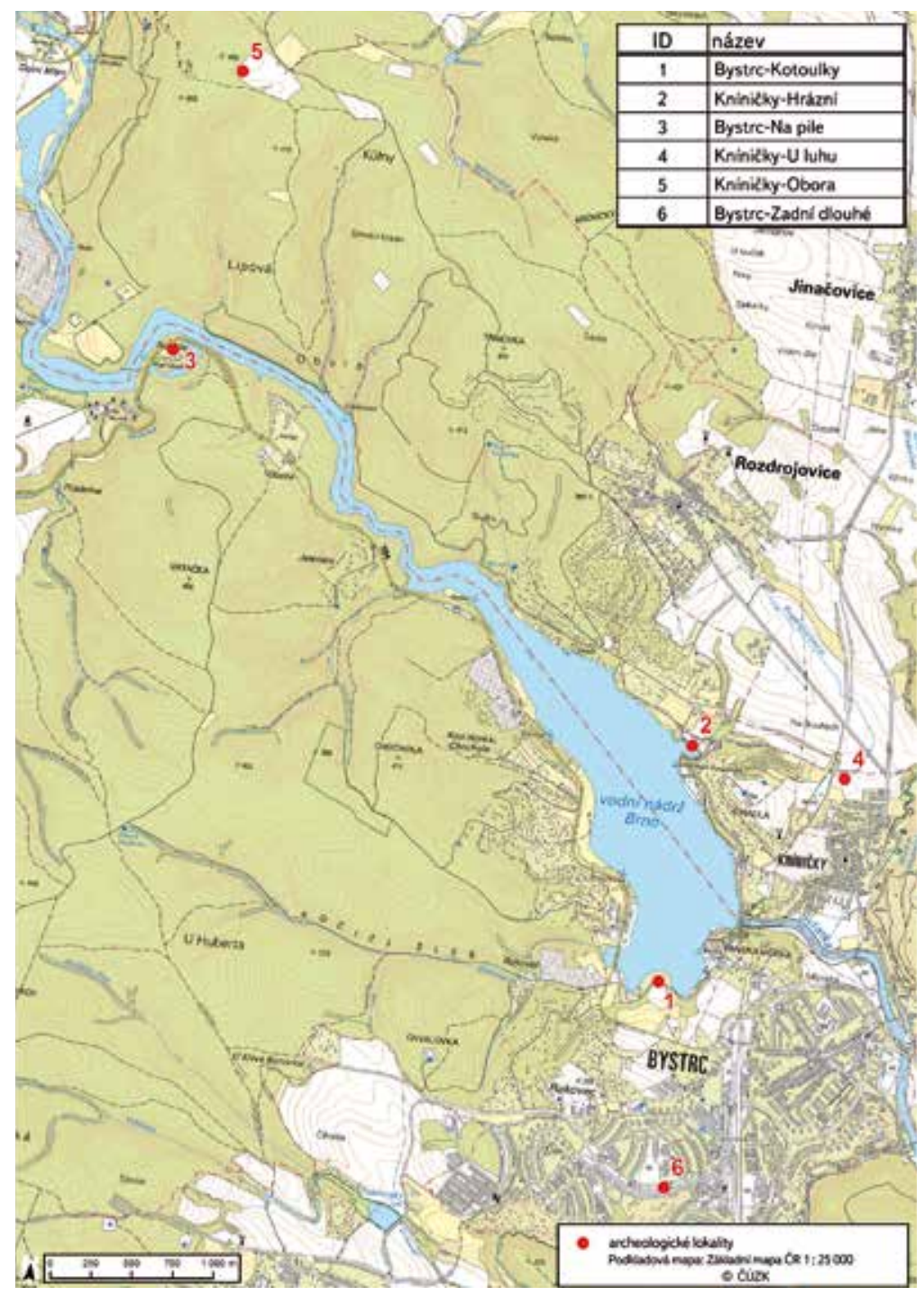

Obr. 3. Archeologické lokality v okolí Brněnské přehrady

Legenda jako u obr. 1.

Fig. 3. Archaeological sites around the Brno Dam

Legend is same as in Fig. 1.

1. Bystrc - Kotoulky (N), 2. Kníničky - Hrázní (N, D), 3. Bystrc - Na pile (N, E), 4. Kníničky U luhu (N), 5. Kníničky - Obora (N), 6. Bystrc - Zadní dlouhé (N) 


\section{BRNĚNSKÁ PŘEHRADA}

Představu, jak bylo v minulosti osídleno území zaplavené vodami Brněnské přehrady, máme jen z nálezů získaných z břehů a ojediněle i ze dna při snížení vodní hladiny (obr.3). Poprvé a na dlouhá tisíciletí i naposledy bylo toto území osídleno $\checkmark$ neolitu. Na tato místa se lidé vrátili až v 11. či 12. stol. Je to doklad poměrně rané kolonizace, při níz lidé pronikali do výše položených území. Není zřejmé, zda to platí i o Kníničkách, doložených písemnými zprávami až od 15. stol. Již od přelomu 12. a 13. stol. stával v předpolí dnešního hradu Veveří knížecí dvorec s kostelem, který v první polovině 13. stol. byl nahrazen zeměpanským hradem [13].

\section{ZÁVĚR}

Rozdíly v průběhu osídlení se projevily především mezi územím v okolí vodního díla Nové Mlýny, ležícího v nížinném prostředí na dolním toku řeky Svratky a Jihlavy, které se zde vlévají do Dyje a Vranovské a Brněnské přehrady, které leží na okraji území osídleného, zřejmě s přestávkami, po celý pravěk. Do okolí Brněnské přehrady pronikli lidé z Dyjsko-svrateckého úvalu v období neolitu a potom již zůstalo toto území až do 11. stol. neosídlené. Okolí Vranovské přehrady, ležící v Bítovské pahorkatině, bylo rovněž na okraji území vhodného pro osídlení v pravěku a časném středověku, ale přesto sem lidé pronikali s menši intenzitou $\vee$ různých obdobích, ale teprve kolonizace, jejiž počátky můžeme sledovat již od 9. stol. a s větší intenzitou od 13. stol., založila osídlení tohoto území trvající dodnes.

\section{Literatura}

[1] SVOBODA, J. Lovci a sběrači - paleolit a mezolit. In: Stuchlík Stanislav, ed.: Oblast vodního díla Nové Mlýny od pravěku do středověku. Brno: Archeologický ústav AVČR 2002, s. 31-55.

[2] ŠEBELA, L. Vývoj neolitického osídlenípod Pavlovskýmivrchy. In: Stuchlík Stanislav, ed.: Oblast vodního díla Nové Mlýny od pravěku do středověku. Brno: Archeologický ústav AVČR 2002, s. 73-90.

[3] ŠEBELA, L. Vývoj eneolitického osídleni pod Pavlovskými vrchy. In: Stuchlík Stanislav, ed.: Oblast vodního díla Nové Mlýny od pravěku do středověku. Brno: Archeologický ústav AVČR 2002, s. 113-132.

[4] STUCHLÍK, S. Vývoj osídleni pod Pavlovskými vrchy v době bronzové. In: Stuchlík Stanislav, ed.: Oblast vodního díla Nové Mlýny od pravěku do středověku. Brno: Archeologický ústav AVČR 2002, s. 149-190. PEŠKA, J.: Protoúnětické pohřebištěz Pavlova. Olomouc: Archeologické centrum 2009

[5] STUCHLIKK, S. Počátky doby železné pod Pavlovskými vrchy. In: Stuchlík Stanislav, ed.: Oblast vodního díla Nové Mlýny od pravěku do středověku. Brno: Archeologický ústav AVČR 2002, s. 223-235.

[6] ČIŽMÁR̆, M. Vývoj laténského osídlenív oblastipod Pavlovskými vrchy. In: Stuchlík Stanislav, ed.: Oblast vodního díla Nové Mlýny od pravěku do středověku. Brno: Archeologický ústav AVČR 2002, s. 249-270. ČIŽMÁŘ́VVÁ, J.: Encyklopedie Keltů na Moravě a ve Slezsku. Praha: Libri 2004.

[7] TEJRAL, J. Doba rímská v oblasti vodního díla. In: Stuchlík Stanislav, ed.: Oblast vodního díla Nové Mlýny od pravěku do středověku. Brno: Archeologický ústav AVČR 2002, s. 291-327.

[8] TEJRAL, J. Region pod Pavlovskými vrchy v době stěhování národü. In: Stuchlík Stanislav, ed.: Oblast vodního díla Nové Mlýny od pravěku do středověku. Brno: Archeologický ústav AVČR 2002, s. 355-363.

[9] JELIÍNKOVÁ, D. a KAVÁNOVÁ, B. Slovanské osídlení v oblasti Vodního díla Nové Mlýny. In: Stuchlík Stanislav, ed:: Oblast vodního díla Nové Mlýny od pravěku do středověku. Brno: Archeologický ústav AVČR 2002, s. 371-391.

[10] UNGER, J. Pozdni středověk a novověk. In: Stuchlík Stanislav, ed.: Oblast vodního díla Nové Mlýny od pravěku do středověku. Brno: Archeologický ústav AVČR 2002, s. 419-425. UNGER, J.: Kostel sv. Linharto v Mušově. Vyhodnocení archeologického výzkumu. Jižní Morava, roč. 50, 2014, s. 217-256. UNGER J.: Voda na soutoku Jihlavy, Svratky a Dyje v lichtenštejnském urbári z roku 1414. In: XXXII. Mikulovské sympozium 2014, Brno: Moravský zemský archiv 2015, s. 32-36.

[11] ČIŽMÁŘ, M. Encyklopedie hradišt' na Moravě a ve Slezsku. Praha: Libri 2004, s. 82. PODBORSKÝ, V. a VILDOMEC, V. Pravěk Znojemska. Brno: Musejní spolek a Jihomoravské muzeum 1972, s. 149, 231 LUTOVSKÝ, M. Encyklopedie slovanské archeologie v Čechách, na Moravě a ve Slezsku. Praha: Libri 2001 s. 363.

[12] SAMEK, B. Umělecké památky Moravy a Slezska 1 /A-I/. Praha: Academia 1994, s. 57. PLAČEK, M Ilustrovaná encyklopedie moravských hradü, hrádků a tvrzí. Praha: Libri 2001, s. 159-161.

[13] PROCHÁZKA, R., red. Dějiny Brna 1. Od pravěku k ranému středověku. Brno: Statutární město a Archiv města 2001, s. 580. 592. PLAČEK, M. Ilustrovaná encyklopedie moravských hradü, hrádků a tvrzí. Praha: Libri 2001, s. 683-687.

\section{Autor}

prof. PhDr. Josef Unger, CSc.

凶unger@sci.muni.cz

Ústav antropologie, Př́rodovědecká fakulta, Masarykova univerzita

Příspěvek prošel lektorským řízením.

\section{PREHISTORIC AND MEDIEVAL SETTLEMENTS IN THE AREA OF THREE CONTEMPORARY SOUTH MORAVIAN DAMS}

\section{UNGER, J.}

Institute of Anthropology, Faculty of Science, Masaryk University

Keywords: archaeology - history of settlements Pavlovské vrchy - Nové Mlýny - Vranov - Brno

All three flooded areas lied in a different natural environment that shaped their fates. Archaeological sources have irreplaceable significance for understanding the changes in settlements. If no archaeological research was carried out before the construction of the Vranov Dam and the Brno Dam and we only depend on the findings from the surroundings, so before the construction of the dam on Dyje, the flooded area was systematically and archeologically investigated.

Differences in settlement occurred mainly between the area around system of water reservoirs of Nové Mlýny, situated in the lowlands on the lower reaches of the river Svratka and Jihlava, which flow into the Dyje and Vranov Dam and Brno Dam, which lie on the outskirts of the inhabited area, apparently with breaks throughout prehistory. 